\title{
Isolate the Socio-Demographic Characteristics of the Farm Women may affect their Nutritional Security
}

\author{
Karishma Baidya ${ }^{1}$, Faruk Ansari ${ }^{2} *$ and Kausik Pradhan ${ }^{3}$ \\ ${ }^{1}$ Indira Gandhi Krishi Viswavidyalaya, Raipur, Chhattisgarh 492001, India \\ ${ }^{2}$ Dr. Yashwant Singh Parmar Horticulture and Forestry University Nauni, Solan, \\ Himachal Pradesh-173230, India \\ ${ }^{3}$ Uttar Banga Krishi Viswavidyala Pundibari, Cooch Behar, West Bengal- 736163, India \\ *Corresponding author
}

\section{Keywords \\ nutrition, farm women, family income, economic empowerment, nutrition knowledge, kitchen garden \\ Article Info \\ Accepted: \\ 18 August 2019 Available Online: 10 September 2019}

\section{A B S T R A C T}

In India,most of the farmer having least cultivated and lower income as a result low annual expenditure on food consumption, here in the study area they have medium to low level of cultivated land that most affect their nutrition security. Agriculture helps in ensuring good nutrition and good nutrition builds human capital which is also an input for agro-production creating a circular pathway between agriculture and nutrition. Undernourished women are often physically weak and unable to perform income-earning activities and household work to their full potential which create worse effects that extend through generations and lead to economic losses for families and countries. Malnutrition disempowers women by causing or aggravating infection, illness, lowering educational attainment and diminishing livelihood skills and drains family savings. Women play a role to save their family easily from nutrition problems with awareness and proper nutrition knowledge. Hence, their extent of knowledge has great importance for the social, economic and nutritional change of the country which, in turn, may contribute to improve the overall nutritional status of people in our country specially women. To recognize this issue conducted a study in the villages of Dhalaguri and Dhanghinguri of Cooch Behar-II block under Cooch Behar district in West Bengal. Purposive, multi-stage sampling procedures are followed in the present study. The district Cooch Behar and block Cooch Behar-II was purposively selected due to the availability of active farming women involved in agriculture and allied sectors. Out of the thirteen (13) Gram Panchayats of Cooch Behar-II block, two (2) villages were randomly selected namely Dhalaguri and Dhanghinguri for the study. Hundred number of respondent were interviewed taking fifty from each village. The study of socio-psychological variables revealed that all of the farm women had the knowledge and practice of including cereals in their diet because of their tradition majority of the farm women possess medium attitude towards nutrition. 


\section{Introduction}

In the era of second green revolution, the highest contributor in Indian economy is the most of the population of the country is residing in rural area and dealing with agriculture from the primitive era the vocation of agriculture is predominate by the women. In this context, one of the agricultural pathway towards sustainable nutritional security is through local production of nutritious food activity in which the farm women where the most vulnerable. Agriculture helps to ensuring good nutrition and good nutrition can build human capital which is also input for agro production, creating a circular pathway between agriculture and nutrition. Despite rapid growth in socio-economic development, health and education, the widening economic, regional and gender disparities are posing challenges for the health sector. Therefore, rural women could be an effective partner and contributor towards the nutritional security of the rural folks because a woman plays an important role in selection, preparation and serving of food for their family members (Kumari and Srivastava, 2010). Their extent of knowledge has great importance for the social, economic and nutritional change of the country which, in turn, may contribute to improve the overall nutritional status of people in our country specially women (Afrin Sultana et al., 2016) (Chatterjee, 1990; Desai, 1994). Finally, a woman's health affects the household's economic well being too. In any country the state of health is measured in terms of life expectancy, mortality rate, fertility rate and many more. But it can't be ignored that all these indicators of health are dependent on other factors like per capita income, nutrition, sanitation, safe drinking water, social infrastructure, medical care facilities, employment status, poverty, etc which affect the health of every individual. Keeping this in view, a study was conducted to know the isolate the socio-demographic characteristics of the farm women that may affect their nutritional security.

\section{Materials and Methods}

The study was conducted in the villages of Dhalaguri and Dhanghinguri of Cooch BeharII block under Cooch Behar district in West Bengal. Purposively, multi-stage sampling procedures were followed in the present study. The district Cooch Behar and block Cooch Behar-II was purposively selected due to the availability of active farming women involved in agriculture and allied sectors. Out of the thirteen Gram Panchayats of Cooch Behar-II block, two villages were randomly selected namely Dhalaguri and Dhanghinguri for the study. 100 farm women were interviewed taking fifty from each village.

\section{Results and Discussion}

The table 1, reveal that the majority of the farm women $(57 \%)$ where under the young age group of 26-37 years followed by the middle age group of $(26 \%)$ who where between 38-49 years and (17\%) of them old age group of 50-61 years. The variability in age of the respondent is distributed with a mean value of 38.41 and standard deviation of 8.64. The coefficient of variation value $22.49 \%$ of the distribution signifies the high consistency level of the distribution for the variable 'age'. Majority of the farm women in the study area are young to middle age group, this gives a scope for extension workers for diffusion of novel technologies to improve nutritional security.

The table 2 reveals that majority of the farm women are under the medium level of family education status 2.8-3.9 (56\%) followed by high level of education status 4.0 to 5.1 (27\%) and low level 1.6 to 2.7 (17\%) respectively. The mean score of total distribution was 3.27 and standard deviation of the distribution was 
0.67 . The coefficient of variation value within the distribution being $20.49 \%$ signifies the very high consistency level of the distribution for the variable 'family education statuses. Kauret al., (2015) observed that education of mother was positively and significantly correlated with the knowledge regarding anemia, pregnancy, hygiene \& sanitation and feeding practices and thereby the nutrition knowledge of the mother was found to have a significant bearing on their children nutritional status. The need of nutrition education for women was, therefore, important and urgent in rural areas. The result indicates that most of the farm women in the study area belong to those families where family education status was medium to high, this may because of majority of the responded young to middle aged who where hold good educated.

The table 3 shows that majority of the farm women were under the low level of family annual income $0.78-1.15(50 \%)$ followed by medium level of family annual income of 1.16-1.53 (45\%) and high level 1.54-1.91 $(5 \%)$ respectively. The mean score of total distribution is 1.16 and standard deviation of the distribution is 0.23 . The coefficient of variation value within the distribution being $19.8 \%$ signifies the very high consistency level of the distribution for the variable 'family annual income'. One of the reasons for low to medium family annual income is that the families' in the study area had low to medium land holding and the primary source of their income is farming. On the contrary, Sheth, et al.,(2006) reported that the monthly family income (from all sources) of majority $(78.5 \%)$ of households ranged between Rs.1000-1500 per month.

The table 4 presents the distribution of the farm women according to their family member. The result shows that majority of the farm women fall under the low family member category 3-4 (66\%) followed by high family member 5-6 (34\%) respectively. The mean score of total distribution is 4.21 and standard deviation of the distribution is 0.84 .

The coefficient of variation value within the distribution being $19.95 \%$ signifies the very high consistency level of the distribution for the variable 'family member.

Table 5 presents the distribution of the farm women according to their land holding. The results show that majority of the farm women are under the low level of land holding 0.56$1.72(61 \%)$ followed by medium level of land holding 1.73-2.89 (31\%) and high level 2.90$4.06(8 \%)$ respectively.

The mean score of total distribution is 1.59 and standard deviation of the distribution is 0.78 . The coefficient of variation value within the distribution being $49.06 \%$ signifies the medium consistency level of the distribution for the variable 'land holding'.

Table 6 presents that the distribution of the farm women according to their annual expenditure. The results show that majority of the farm women fall under the medium level of family expenditure 0.72-0.97 (44\%) followed by low level of annual expenditure 0.46-0.71 (20\%) and high level 0.98-1.23 (6\%) respectively. The mean score of total distribution is 0.76 and standard deviation of the distribution is 0.14 .

The coefficient of variation value within the distribution being $18.42 \%$ signifies the very high consistency level of the distribution for the variable 'annual expenditure'.

It indicated that the farm women having medium expenditure. It is notices in the study area both the family annual income and annual expenditure, majority of the farm women are in low and medium category. 
$(n=100)$

\begin{tabular}{|c|c|c|c|c|c|c|}
\hline \multicolumn{4}{|c|}{$\begin{array}{l}\text { Table.1 Distribution of farm women according to their } \\
\text { age }\left(\mathrm{X}_{1}\right)\end{array}$} & \multicolumn{3}{|c|}{$\begin{array}{l}\text { Table. } 2 \text { Distribution of the farm women } \\
\text { according to family education status }\left(\mathrm{X}_{2}\right)\end{array}$} \\
\hline Category & Score & Frequency & Percentage & Score & Frequency & Percentage \\
\hline Young aged & $26-37$ & 57 & 57 & $1.6-2.7$ & 17 & 17 \\
\hline Middle aged & $38-49$ & 26 & 26 & $2.8-3.9$ & 56 & 56 \\
\hline Old aged & $50-61$ & 17 & 17 & $4.0-5.1$ & 27 & 27 \\
\hline Statistics & \multicolumn{3}{|c|}{$\begin{array}{c}\text { Range }=26-60, \text { Mean }=38.41 \\
\mathrm{SD}=8.64, \mathrm{CV}=22.49 \%\end{array}$} & \multicolumn{3}{|c|}{$\begin{array}{c}\text { Range }=1.6-5.0, \text { Mean }=3.27 \\
\mathrm{SD}=0.67, \mathrm{CV}=20.49\end{array}$} \\
\hline
\end{tabular}

$(n=100)$

\begin{tabular}{|c|c|c|c|c|c|c|}
\hline \multicolumn{4}{|c|}{$\begin{array}{l}\text { Table.3 Distribution of the farm women according to } \\
\text { family annual income }\left(\mathrm{X}_{3}\right)\end{array}$} & \multicolumn{3}{|c|}{$\begin{array}{l}\text { Table.4 Distribution of the farm women } \\
\text { according to family member }\left(\mathrm{X}_{4}\right)\end{array}$} \\
\hline Category & Score & Frequency & Percentage & Score & Frequency & Percentage \\
\hline Low & $0.78-1.15$ & 50 & 50 & $3-4$ & 66 & 66 \\
\hline Middle & $1.16-1.53$ & 45 & 45 & 0 & 0 & 0 \\
\hline High & $1.54-1.91$ & 5 & 5 & $5-6$ & 34 & 34 \\
\hline Statistics & \multicolumn{3}{|c|}{$\begin{array}{c}\text { Range }=0.78-1.90, \text { Mean }=1.16 \\
\mathrm{SD}=0.23, \mathrm{CV}=19.83\end{array}$} & \multicolumn{3}{|c|}{$\begin{array}{c}\text { Range }=3-6, \text { Mean }=4.21 \\
\mathrm{SD}=0.84, \mathrm{CV}=19.95\end{array}$} \\
\hline
\end{tabular}

$(n=100)$

\begin{tabular}{|c|c|c|c|c|c|c|}
\hline \multicolumn{4}{|c|}{$\begin{array}{l}\text { Table.5 Distribution of the farm women according to } \\
\text { land holding }\left(\mathrm{X}_{5}\right)\end{array}$} & \multicolumn{3}{|c|}{$\begin{array}{l}\text { Table.6 Distribution of the farm women } \\
\text { according to annual expenditure }\left(\mathrm{X}_{6}\right)\end{array}$} \\
\hline Category & Score & Frequency & Percentage & Score & Frequency & Percentage \\
\hline Low & $0.56-1.72$ & 61 & 61 & $0.46-0.71$ & 44 & 44 \\
\hline Medium & $1.73-2.89$ & 31 & 31 & $0.72-0.97$ & 50 & 50 \\
\hline High & $2.90-4.06$ & 8 & 8 & $0.98-1.23$ & 6 & 6 \\
\hline Statistics & \multicolumn{3}{|c|}{$\begin{array}{c}\text { Range }=0.50-4.00, \text { Mean }=1.59 \\
\qquad \mathrm{SD}=0.78, \mathrm{CV}=49.06\end{array}$} & \multicolumn{3}{|c|}{$\begin{array}{c}\text { Range }=0.46-1.20 \text { Mean }=0.76 \\
\qquad \mathrm{SD}=0.14 \mathrm{CV}=18.42\end{array}$} \\
\hline
\end{tabular}


$(n=100)$

\begin{tabular}{|c|c|c|c|c|c|c|}
\hline \multicolumn{4}{|c|}{$\begin{array}{l}\text { Table.7 Distribution of the farm women according } \\
\text { to food expenditure }\left(\mathrm{X}_{8}\right)\end{array}$} & \multicolumn{3}{|c|}{$\begin{array}{l}\text { Table.8 Distribution of the farm women } \\
\text { according to extension contact }\left(\mathrm{X}_{9}\right)\end{array}$} \\
\hline Category & Score & Frequency & Percentage & Score & Frequency & Percentage \\
\hline Low & $0.35-0.53$ & 67 & 67 & $8-11$ & 54 & 54 \\
\hline Medium & $0.54-0.72$ & 30 & 30 & $12-15$ & 42 & 42 \\
\hline High & $0.73-0.91$ & 3 & 3 & $16-19$ & 4 & 4 \\
\hline Statistics & \multicolumn{3}{|c|}{$\begin{aligned} \text { Range } & =0.35-0.89, \text { Mean }=0.51 \\
\text { SD } & =0.09, C V=17.69\end{aligned}$} & \multicolumn{3}{|c|}{$\begin{array}{c}\text { Range }=8-18, \text { Mean }=11.17 \\
\mathrm{SD}=2.21, \mathrm{CV}=19.79\end{array}$} \\
\hline
\end{tabular}

Table.9 Distribution of the farm women according to mass media exposure $\left(\mathrm{X}_{10}\right)$

\begin{tabular}{|c|c|c|c|c|}
\hline Category & Score & Frequency & Percentage & Statistics \\
\hline Low & $2-4$ & 48 & 48 & \multirow{3}{*}{$\begin{array}{l}\text { Range }=2-10 \\
\text { Mean }=5.19 \\
\mathrm{SD}=1.49 \\
\mathrm{CV}=28.32\end{array}$} \\
\hline Medium & $5-7$ & 46 & 46 & \\
\hline High & $8-10$ & 6 & 6 & \\
\hline
\end{tabular}

Malnutrition disempowers women by causing or aggravating infection, illness, lowering educational attainment and diminishing livelihood skills and drains family savings (Alam, et al., 2011). And,Daba, et al.,(2013) reported that less $(34.8 \%)$ respondents had the knowledge that inadequate nutrition during pregnancy can be the cause of miscarriage and pre-term birth.

The table 7 reveals the distribution of the farm women according to their food expenditure. The results show that majority of the farm women fall under the low food expenditure category $0.35-0.53(67 \%)$ followed by medium category of food expenditure 0.54 0.72 (30) and high category 0.73-0.91 (3\%) respectively. The mean score of total distribution is 0.51 and standard deviation of the distribution is 0.09 . The coefficient of variation value within the distribution being $17.69 \%$ signifies the very high consistency level of the distribution for the variable 'food expenditure. It indicates that the farm women having low food expenditure which needs to be enhance through various awareness and campaigns on spending on nutritious food. (Chatterjee, 1990). Because of prevailing culture and traditional practices in India, the health and nutritional status of women becoming worse effected.

The table 8 reveals the distribution of the farm women according to their extension contact. The results shown that majority of the farm women fall under low level of extension contact 8-11 (54\%) followed by medium level of extension contact 12-15 (42) and high category 16-19 (4\%) respectively. The mean score of total distribution was 11.17 and standard deviation of the distribution was 2.21. The coefficient of variation value within the distribution being $19.79 \%$ signifies the very high consistency level of the distribution for the variable 'extension contact. It indicates that most of the farm women in the study area do not have contact with extension functionaries which often restrict them from getting firsthand information regarding nutritional aspect of food intake.

The table 9 presents the distribution of the 
farm women according to their mass media exposure. The results show that majority of the farm women fall under the low mass media exposure 2-4 (48\%) followed by medium mass media exposure 5-7 (46) and high 8-10 (6\%) respectively. The mean score of total distribution was 5.19and standard deviation of the distribution was 1.49. The coefficient of variation value within the distribution being $28.32 \%$ signifies the high consistency level of the distribution for the variable 'mass media exposure'. It indicates that most of the farm women in the study area do not have adequate exposure to mass media which often restricts them from getting appropriate information regarding nutritional aspect of food intake.

Most of the farm women in the study area have no land to cultivate, illiterate along with less farming experience, so nutrition education and awareness programmes need to conduct in that area to create nutrition sensitivity among them and as they were mostly young ages so it will be easy to change their mindset and motivate them to grow some green nutritious vegetables in their kitchen garden through training programmes, also might be encourage them to engage in some income generation activities to support their family income and make them economically empowered which will reflect to improve their family nutrition status.

\section{References}

Alam K, Tasneem and Oliveras E.(2011). Performance of female volunteer community health workers in Dhaka urban slums: A case-control study. A Manoshi working paper.No. 12.International Centre for Diarrhoeal Disease Research, Dhaka, Bangladesh; Research and Evaluation Division, BRAC.

Chatterjee, M.(1990). Indian women: Their Health and Economic productivity. World Bank Discussion Papers, 109, Washington, D.C: World Bank.

Daba G, Beyene F, Fekadu H, GaromA. W (2013) Assessment of Knowledge of Pregnantb Mothers on Maternal Nutrition and Associated Factors in GutoGidaWoreda, East Wollega Zone, Ethiopia. J Nutr Food Sci3: 1-7

KaurK, Grover K andKaur N(2015). Assessment of Nutrition Knowledge of Rural Mothers and Its Effectiveness in Improving Nutritional Status of Their Children. Indian Research Journal Extension Education, 15(4):90-98.

Kumari M., Srivastava A. K and Sinha N. (2010).Extent of Knowledge of Farm Women on Nutrition. Indian Research Journal Extension Education. January 10 (1);65-68.

Sheth M, Gurudasani R, Mistry V, Mehrotra S and Seshasri S (2006) Food safety education as an effective strategy to reduce diarrhoeal morbidities in children less than two years of age. Ind J NutrDietet,43: 2231.

Sultana A, Md. Safiul Islam Afrad, Muhammad ZiaulHoque and Bhattacharjee D (2016).Knowledge of Farm Women on Nutritional Value of Farm Products in Bangladesh.Indian Research Journal Isolate the Socio-Demographic Characteristics of the Farm Women may affect their Nutritional Security Extension Education.16 (2):25-30.

\section{How to cite this article:}

Karishma Baidya, Faruk Ansari and Kausik Pradhan. Techniques for Determination of Vitamin $\mathrm{B}_{6}$, Vitamin $\mathrm{C}$ and Variability in Areca Nut (Areca catechu) Samples of Karnataka, India. Int.J.Curr.Microbiol.App.Sci. 8(09): 1550-1555. doi: https://doi.org/10.20546/ijcmas.2019.809.177 